\title{
Dynamic Characteristics of the Interconnections Urging the Construction Enterprises Development and Regions Economic Growth
}

\author{
Anatoliy Mokiy ${ }^{1}$, Olha Ilyash ${ }^{2}$, Yuriy Pynda ${ }^{3}$, Mariia Pikh ${ }^{4}$,Vitalii Tyurin ${ }^{5}$ \\ ${ }^{I}$ M. Dolishniy Institute of Regional Research of National Academy of Sciences of Ukraine, Regional Economic \\ Policy Department, 4 Kozelnytska Str, 79026, Lviv, Ukraine \\ ${ }^{2}$ International University of Finance, National Technical University of Ukraine "Igor Sikorsky Kyiv \\ Polytechnic Institute”, Department of Theoretical and applied Economy, 37, Prosp. Peremohy, 03056, \\ Kyiv, Ukraine, \\ ${ }^{3}$ Lviv University of Business and Law, Department of Enterprises Economics and Information Technology,99, \\ Kulparkivska str., 79021, Lviv, Ukraine \\ ${ }^{4}$ Lviv State College of Food and Processing Industry, National University of Food Technologies, Cyclic \\ Commission of Accounting and Tax,42Puliuia Str, 79060, Lviv, Ukraine \\ ${ }^{5}$ The National Defense University of Ukraine named after Ivan Cherniakhovskyi, The Aviation and Air Defense \\ Institute, Povitroflotsky avenue, 28, 03049, Kyiv, Ukraine
}

\begin{abstract}
The proposed modelling of the construction sector and its impact on the economic system of Ukraine based on fuzzy logic methods allowed to optimize the value of industry components due to changes in gross regional product. High adaptability of the used models confirms probability to make a choice of the best strategy of development of the state taking into account the construction potential in particular regions in Ukraine. The scientific value of the research lies in the use of dynamic models of the system to study the relationships of the elements of the micro and mezolevel subsystems. The forecast models reflect the value of the state regulatory policy in developing strategic priorities for economic growth.
\end{abstract}

DOI: 10.18421/TEM94-30

https://doi.org/10.18421/TEM94-30

Corresponding author: Olha llyash,

International University of Finance, National Technical University of Ukraine "Igor Sikorsky Kyiv Polytechnic Institute", Department of Theoretical and applied Economy, 37, Prosp. Peremohy, Kyiv, Ukraine, 03056.

Email: oliai@meta.ua

Received: 29 June 2020.

Revised: 16 October 2020.

Accepted: 21 October 2020.

Published: 27 November 2020.

(cc) BY-NC-ND (C) 2020 Anatoliy Mokiy at al; published by UIKTEN. This work is licensed under the Creative Commons Attribution-NonCommercial-NoDerivs 4.0 License.

The article is published with Open Access at www.temjournal.com
Keywords - Construction Sector, Enterprises, Regional Economy, Macrosystems, Forecast Models, Development.

\section{Introduction}

Modern economic conditions in a period of significant macroeconomic imbalances and accumulated problems against the background of the spread consequences of financial and economic, banking and political instability require intensifying the development of dominant economic sectors. At the same time, improving the population living standards and the competitiveness of economic entities depend on the dynamics of development within fund-forming industries.

At different stages in the development of economics, researchers on macroeconomic phenomena and processes in their work have noted the significant participation of construction sector in the expanded reproduction. Despite the significant impact on the economic security of the state, and due to the violation of key goals and strategic priorities of its operation, the construction sector, becomes a significant risk in source presenting on socioeconomic threats for future periods, which are manifested through the prism of social, economic, institutional, technological and environmental aspects.

It should be noted that construction companies, as well as the economy of Ukraine as a whole, face long-term systemic challenges that reflect both global trends and national obstacles on the way to 
development. First of all, it is about increasing global competition; a new wave of technological change, which strengthens the role of innovation (new technological base is formed, based on the use of IT and nanotechnology); the increasing role of human capital as a major factor in economic development; nearly exhausted potential of the export-raw material model of economic development in Ukraine; the presence of high administrative barriers, creating an artificial shortage of availability land, insufficient development of transport and engineering infrastructure, as well as a shortage of qualified human resources in engineering and construction. Furthermore, it is important to thoroughly study the dynamic relationship between the development of the construction sector and economic growth of the regions, as well as forecasting the impact of factors in the development of the construction sector within the regions on economic growth. The whole range of outlined problems is presented in this research article.

\section{Literature Review}

The scientific debate of the study of the dynamic interconnections between the development of the construction sector and the growth of the regional economy could be presented in three directions. The first one is primarily related to highlighting the role and features of the construction sector in the socioeconomic development of the country. L. Kalinichenko and R. Sidorova [1] are convinced that construction is a priority and multi-diversified area of the national economy, which ensures the development of small and medium-sized businesses. Besides, the effective development of the economy construction sector contributes to economic growth of the country and solving social problems in the region. In addition, one should emphasize the lack of relationship between the development of construction entities at the regional level and the development of the construction industry of the state. Thus, N. Fisunenko [2] proves that the level of competitiveness of the state construction sector level is low due to lack of financial and organizational transformations within the industry. And at the same time, the economic growth of construction companies in central districts and large cities is ensured by their investment attractiveness and significant industrial potential. According to $\mathrm{O}$. Latysheva and A. Saiko [3], the economic essence of the economy construction sector functioning is the formation and reproduction of fixed capital at the meso and macro levels, as construction subjects are infrastructural elements of many sectors in the national economy. Therefore, the sustainable development of Ukraine's economy and its economic growth is possible while providing a stable relationship of all elements of the industry in a changing environment of regional development. M. Tatar [4] is convinced that substantiation of influence by external factors on resource potential of the construction sector enterprises could allow solwing a problem of external adaptation of the branch enterprises in the conditions of the changed external environment, and therefore, will promote maintenance of their economic development.

The second direction concerns a comprehensive study of the impact by the interconnections of business entities in the construction industry and other economic activities on the economic development of the region. In particular, the research concerns the justification for systematization of technical, economic and organizational relations between economic entities of different sectors of the national economy, their participation in regional development and growth of gross regional product.Thus, N. Bogdan [5] proves the compatibility of effective interaction of construction companies with enterprises of the construction industry, which sell construction products. The author is convinced that the construction industry is one of the key sectors of the national economy, so the efficiency of the construction industry is an indicator of economic growth. Therefore, any disruption of the interactions inevitably leads to the destruction of the system, and, ultimately, to a slowdown in the regional economy. T. Lichman [6], proposes to consider the reverse effect of the external environment on the construction industry functioning, which ultimately leads to damage to the meso-level system. It is also worth noting the construction industry researchers, including $\mathrm{K}$. Karpova [7], who justifies the impact of destabilizing factors on the climatic conditions in a particular region where construction takes place, namely due to the possibility of occurrence and frequency of natural disasters, their eventual influence on the economic cycle of the region and the national economy as a whole. N.Momot, I. Filatova and O. Tofanyuk [8] are convinced that the normal functioning of construction companies is provided only with minor changes in the external environment, which cannot adversely affect their activities and promote the efficient use of resources by construction companies to ensure expanded reproduction of basic state funds and obtaining a multiplier effect from investing in the construction sector.

And, finally, the third direction of scientific research is concerning the modeling of entities development in construction sector and the influence of their functioning factors on economic growth. Thus, Ilyash, O. et al. [9] reveal a step-by-step method of evaluating the enterprise in terms of economic development using the appropriate 
evaluation parameters at the macro, meso and micro levels. Significant in this context is the justification of the feasibility on using a methodological approach proposed and detaily described by the authors A. Mokiy atall. [10] тa Y. Pynda [11] The research methodology proposed by the authors includes a number of step-by-step processes of research comprising socio-economic indicators of development in the construction sector, which, namely, is used in this study and detaily described in the section "research methods". A number of studies on the use of methods of integrated assessment within socio-economic systems at different hierarchical levels should be noted. In particular, Yu. Kharazishvili and A. Sukhorukov [12] proposed a methodology for integrated assessment based on the multiplicative form of the integrated system development index. The advantage of this method while modeling the development of construction entities is the rationing of indicators and their threshold values, the choice of weights coefficients regarding system elements (industry) and the justification of integrated threshold values of indicators of construction companies. Along with this, M. Klimenko at al. [13] believes that the formalization of system models for assessing the effectiveness of the construction industry is a complex technique on the one hand, and on the other - is separated from the inclusion of redundant indicators in the process of multifactor modeling. The most acceptable in this context is the use of fuzzy set theory and methodology. In fact, $\mathrm{O}$. Rothstein [14] proposed a mathematical model for assessing the development of the system, which could adequately formalize the value, having a flexible structure and a high ability to adapt the expert data. The methods of fuzzy logic allowed the authors in this study to calculate the impact of the construction sector on the economic development of the region and to reflect its participation in the economic macrosystem.

\section{Research Methods and Instruments}

Based on the analysis of the types of construction works performed by enterprises, the dynamics of the deformation of their structure and a significant reduction in the number of construction enterprises with a predominance of small ones were determined. To reveal common regional factors regarding the development of enterprises in the construction sector on the basis of multidimensional statistical analysis (cluster analysis) a matrix was formed, consisting of 32 indicators in terms of all regions of Ukraine over the years 2013 to 2018 .

Based on the method of main components, the structure of the construction sector was aggregated of five components: 1) labor-resource; 2) productive; 3 ) raw materials and resources; 4) financial and investment; 5) foreign economic, each of which has a different degree of influence on the construction sector development. Taking into account the territorial peculiarities of the functioning of construction enterprises, the weight coefficients for each component of the development in the construction sector of the economy by regions were calculated, and on their basis the integrated indices were determined.

The study developed a socio-economic participation model of the construction sector enterprises in the economic system of the state, which is based on the theory of fuzzy logic, allowing us to determine the ranges of influence values of labor, productive, raw materials, financial and investment and foreign economic components of the construction sector in gross regional product (GRP), and to calculate the projected values levels. Modelling of the construction sector development using fuzzy sets was carried out on the basis of the objective function:

$$
f_{j}=\max _{t}\left\{\begin{array}{c}
\max \left\{\begin{array}{c}
\sup \left(\min \left\{\mu_{x_{i}}(x), \mu_{x_{i}}(x)\right\}\right) \\
i
\end{array}\right\} X_{i}
\end{array}\right\}
$$

where $X_{i}$ is the region of the values of the i-th parameter $(i=\overline{1,5}) ; \quad \mu_{x_{i} t}$ - the functions of the membership of fuzzy subsets within the main elements of the subsystem of the construction in the region, where $i=1,5 ; t=1,6$.

Integral indices of development of the construction sector components are chosen as independent variables $\left(x_{1}, x_{2}, x_{3}, x_{4}, x_{5}\right)$, and dependent variables the share of construction in GRP (Y). Based on the use of the Mamdani algorithm (fuzzy inference), a linguistic estimation of the parameters (with normalized values) for the input and output variables was performed and the levels of their influence were calculated.

\section{Results}

Solving large-scale economic problems, construction companies have to form orders to find the optimal technical, technological and organizational solutions having a multiplier effect for the whole economy. At the same time, they need quantitative and qualitative transformations to effectively meet the tasks of increasing the volume of housing construction, the implementation of largescale infrastructure projects by giving opportunities for the development of industrial and economic potential of Ukraine as a whole.

Within the years 2010-2019 there was a deformation of the structure of the construction works carried out by the companies. 
Over the years 2010-2018, small businesses achieved dominance in the areas of housing construction and specialized construction works, while the number of medium and large businesses decreased significantly: share in residential and commercial construction from 868 to 491 units (including the number of large enterprises, from 6 to 2); Erection of engineering structures - from 287 to 167 units (number of big businesses did not change - 4 enterprises); performing specialized construction work- from 355 to 217 (none large enterprises) (Fig.1).

\section{Residential and non-residential buildings (thousand \$ dollars )}
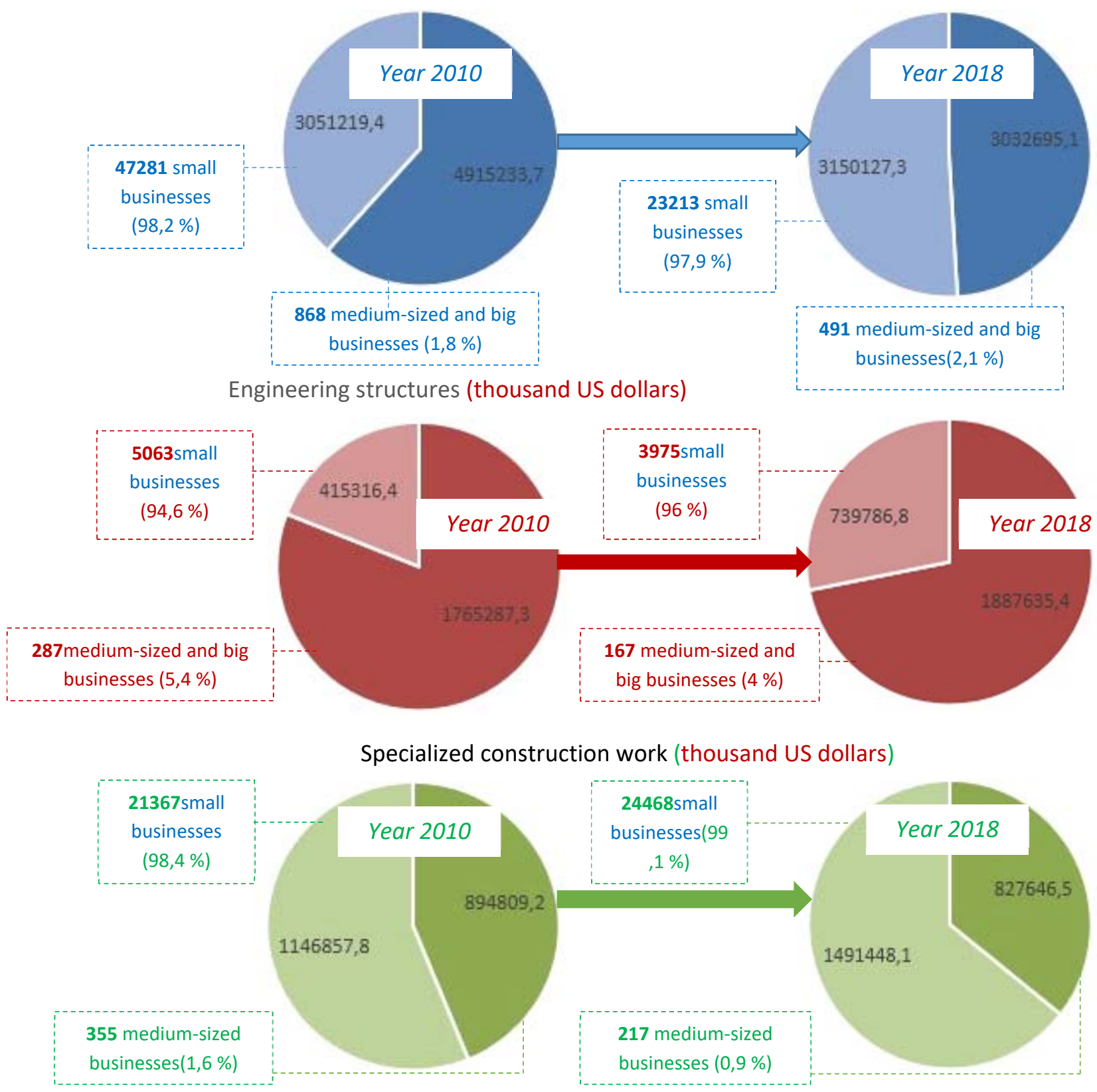

Figure 1. Dynamics of sales volumes by construction enterprises in Ukraine, by their size

Source: formed for [15]

To reveal common regional factors for the development of the construction sector enterprises, a matrix was formed, which consisted of 32 indicators in terms of all regions of Ukraine in 2013 and 2018. Due to results of multidimensional statistical analysis (BAS) in 2018, 6 taxonomic groups (clusters) of regions were reveald by level of the construction sector development, in 2013 - 7, which does not allow to specify the common features for a particular regions group, however, confirming the significant changes that took place in the construction by different regions overtheyears 2013-2018. (Fig. 2; 3). 


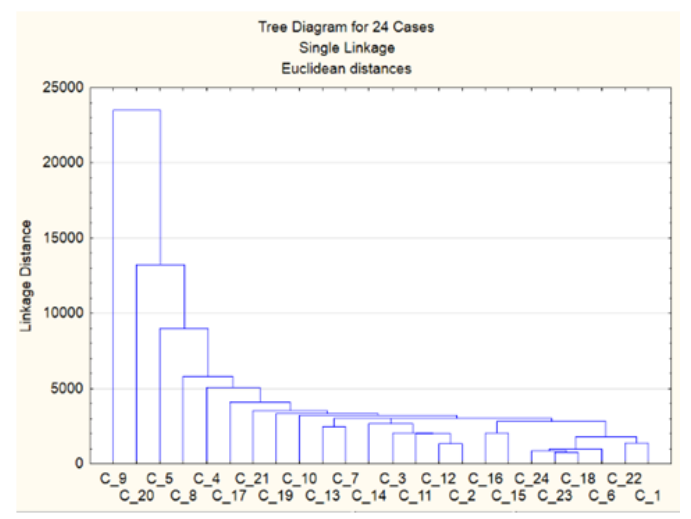

Figure 2. Visual representation of the cluster analysis results on the plotted "combination tree",2013.

Source: Authors' calculations

With a regard to the fact that construction companies operate in terms of functional interconnectivity of a number of the construction sector components (vertically and horizontally integrated), designed to ensure the implementation of common socio-economic goals and objectives, we can assume that they have all the signs of systemic interconnection between elements [10],[11]. The multiplicative form of the integral index is used on the basis of the integral estimation by means of a method of principal components. Among its relative

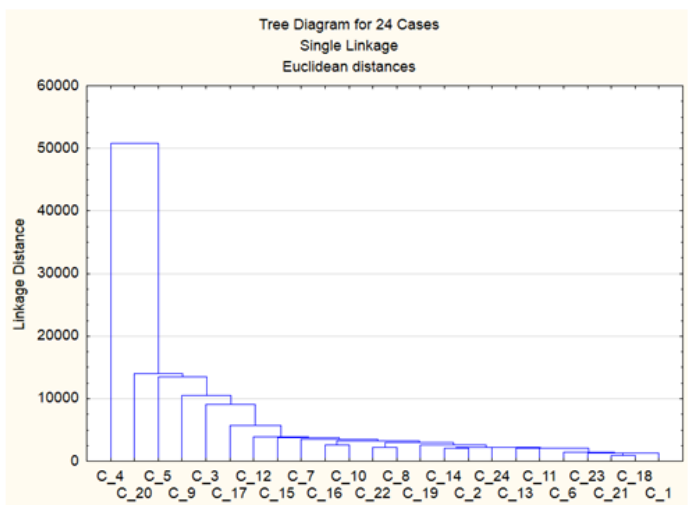

Figure 3. Visual representation of the cluster analysis results on the plotted "combination tree",2018.

Source: Authors' calculations

advantages it is necessary to note the possibility of aggregation of multi-vector indicators, to display their nonlinear relations and simultaneous rationing, to establish their threshold values and to make a formalized substantiation of weights coefficients while integrated evaluation of indicators is achieved. The integrated indicator of the dynamics of the subsystem development in construction sector is calculated according to following sequence (Table. 1):

Table 1.Methodology for calculating the integrated indicator of the dynamics of the subsystem development in construction sector and the country's macrosystem

\begin{tabular}{|c|l|}
\hline \multicolumn{1}{|c|}{ Calculation formula } & \multicolumn{1}{c|}{ Characteristics of values } \\
\hline$I_{t}=\prod_{i=1}^{n} z_{i t} * a_{i} ; \sum_{i=1}^{n} a_{i}=1 ; \quad a_{i} \geq 0$ & $\begin{array}{l}\text { where } I_{t}-\text { is an integral indicator of dynamics of construction } \\
\text { sector subsystem development; } z_{i, t}-\text { normalized annual values of the } \\
\text { indicators } t, t=1, T ; a_{i,}-\text { weight annual coefficients; } i=1, n .\end{array}$ \\
\hline$y_{t}=\sum_{i=1}^{m} c_{i t} G_{t}$ & $\begin{array}{l}\text { where } y_{t}-\text { are standardized values, } I \text { - single dispersion components } \\
\text { per year } t ;=1, T-\text { years of the researched period;total variance is } \\
\text { equal to the number of features } m ; c_{i t}-\text { contribution of } i- \\
\text { component in total dispersion set of indicators per year } t ; i=1, m- \\
\text { the number of features. }\end{array}$ \\
\hline$G_{t}=\sum_{i=1}^{n} d_{i t} x_{i t}$ & $\begin{array}{l}\text { where } d_{i t}-\text { are load factors; } x_{i t}-\text { data-in; } i=1, n-\text { the number of } \\
\text { features; } t=1, T-\text { years of the researched period. }\end{array}$ \\
\hline$a_{i}=\frac{c_{i}\left|d_{i}\right|}{\sum_{i=1}^{n} c_{i}\left|d_{i}\right|}$ & $\begin{array}{l}\text { where } a_{i,}-\text { weight annual coefficients; } c_{i t}-\text { contribution of } i- \\
\text { component in total dispersion set of indicators per year } t ; d_{i t}-\text { are } \\
\text { load factors. }\end{array}$ \\
\hline
\end{tabular}

Source:completed by authors based on [10],[12],[16]

Given the presence of direct and indirect interconnections between components of the construction sector and the dependence of GRP on them, as well as the complexity of their sufficiently complete quantification, which limits the possibilities of modelling, the formation of fuzzy estimation algorithm was carried out using fuzzy sets [17]. Therefore, the set $\mathrm{S}$ is defined as:

$$
S=\mu_{i}(x)
$$

where $\mu_{i}(x)$ - is the function of the rating of the situation with the $i$-parameter (C. Gil, 2001).

Based on the MatLab platform and the Fuzzy Logic Toolbox package the process of fuzzy modelling of GRP condition assessment under the 
influence of components of the construction sector, characterized by a set of indicators $M: X=\left(x_{i}\right)$, where, $i=\overline{1, M}-$ is a set of indicators.

In accordance with the proposed methodological approach, the sequence of which was highlighted in detail in previous studies [10],[11], the assessment of opportunities for development of the construction sector based on identifying functional interconnections with the country's macrosystem needs formalization its structure and system-dynamic modelling [13] The main components, which demonstrates the different degree of importance for the development of the construction industry through the prism of their regional features, were aggregated. (Table 2).

Table 2. Dominant components of the construction sector by regions

\begin{tabular}{|c|c|c|}
\hline $\begin{array}{c}\text { The name of the component } \\
\text { the construction sector }\end{array}$ & Characteristic & Regional level \\
\hline 1) Labor-resource $\left(x_{1}\right)$ & $\begin{array}{l}\text { personnel and social } \\
\text { productivity }\end{array}$ & $\begin{array}{l}\text { the labor-resource component is characterized by } \\
\text { the greatest values of integrated indexes, namely, } \\
\text { the most significant influence on the development } \\
\text { of the construction subsystem in the regions; The } \\
\text { largest values are observed in Dnipropetrovsk } \\
\text { (integrated index is } 0,565) \text {, Zaporizhya }(0,544) \text {, } \\
\text { Rivne }(0,582) \text {, Sumy }(0,639) \text {, Kharkiv }(0,616) \\
\text { and Chernivtsi }(0,672) \text { regions }\end{array}$ \\
\hline 2) Productive $\left(x_{2}\right)$ & $\begin{array}{l}\text { results of functioning of the } \\
\text { construction subsystem are } \\
\text { reflected by indicators of } \\
\text { commissioning of housing }\end{array}$ & $\begin{array}{l}\text { the productive component is marked by a } \\
\text { significant influence in most areas, although in } \\
\text { some regions the integrated indexes are relatively } \\
\text { low (Zaporizhya - } 0.081 \text { due to low volumes of } \\
\text { housing construction), Donetsk }(0.022) \text { and } \\
\text { Luhansk (0.020) regions (as a result of the } \\
\text { military occupation actions of a part of territory) }\end{array}$ \\
\hline $\begin{array}{l}\text { 3) Raw material resource } \\
\text { component }\left(x_{3}\right) \text {; }\end{array}$ & $\begin{array}{l}\text { state of the subsystem and } \\
\text { related branch subsystems of the } \\
\text { construction industry, reflected } \\
\text { by indicators of volumes of } \\
\text { extracted building raw materials } \\
\text { and building materials } \\
\text { production }\end{array}$ & $\begin{array}{l}\text { the raw material and resource component is } \\
\text { characterized by a low level of integrated indexes, } \\
\text { which reflects the natural and resource-rich } \\
\text { supply of building materials and production of } \\
\text { basic building materials favorable for few regions } \\
\text { (Zhytomyr - } 0.109 \text {, Kyiv - } 0.212 \text {, Lviv - } 0.173 \text {, } \\
\text { Khmelnytsky - } 0.102 \text { regions) }\end{array}$ \\
\hline $\begin{array}{l}\text { 4) Finance and investment } \\
\text { component }\left(x_{4}\right)\end{array}$ & $\begin{array}{l}\text { financial elements of the } \\
\text { construction sub-system } \\
\text { (enterprises) and sector } \\
\text { investment capacity }\end{array}$ & $\begin{array}{l}\text { the financial and investment component reflects } \\
\text { the low level of integrated indexes. The } \\
\text { prerequisites for their relatively higher values } \\
\text { were in the Dnipropetrovsk }(0.110) \text {, Ivano- } \\
\text { Frankivsk }(0.158) \text {, Lviv }(0.177) \text {, Mykolaiv } \\
(0.296) \text {, Odessa }(0.185) \text {, Rivne }(0.138) \text {, Ternopil } \\
(0.269) \text { and Kharkiv (0.204) regions due to } \\
\text { favorable financial condition of construction } \\
\text { enterprises and high sectoral investment capacity }\end{array}$ \\
\hline 5) Foreign trade $\left(x_{5}\right)$ & $\begin{array}{l}\text { volumes of import-export } \\
\text { operations in the construction } \\
\text { subsystem }\end{array}$ & $\begin{array}{l}\text { the foreign economic component is characterized } \\
\text { by the lowest level of integrated indexes due to a } \\
\text { significant share of imports of building materials } \\
\text { in terms of services and non-significant volumes } \\
\text { of their exports, except Kherson }(0.319) \text { and } \\
\text { Cherkassy }(0.101) \text { regions }\end{array}$ \\
\hline
\end{tabular}

Source:completed by authors based on [10],[13], [18]

Based on the aggregation results of the main components of the Ukrainian construction sector by regions, their integrated indices were determined $\left(x_{1}\right.$, $\left.x_{2}, x_{3}, x_{4}, x_{5}\right)$ - independent variables, and the share of construction in GRP was chosen as dependent variables $(Y) ; X=\left(x_{i}\right), i=1,5$ - the number of the construction subsystem components. To confirm the hypothesis of the study, it is important to determine the outlined interconnections in their dynamics. A subset of indicators have to be defined for each component $X_{r}=\left(x_{i r}\right), i=1,5 ; r=1,28$. A subset of indicators over a six-year research period (2013$2018)$ is displayed as follows: $X_{r t}=\left(x_{i r t}\right)$, where $x-$ is a regional complex construction parameter, $i=1,5$ and $t=1,6$ [19]. (Fig. 4). Therefore:

$$
\forall i=\overline{1 ; 5} \quad X_{i} \subset X ; \quad \forall t=\overline{1 ; 5} \quad X_{i t} \subset X_{r}
$$




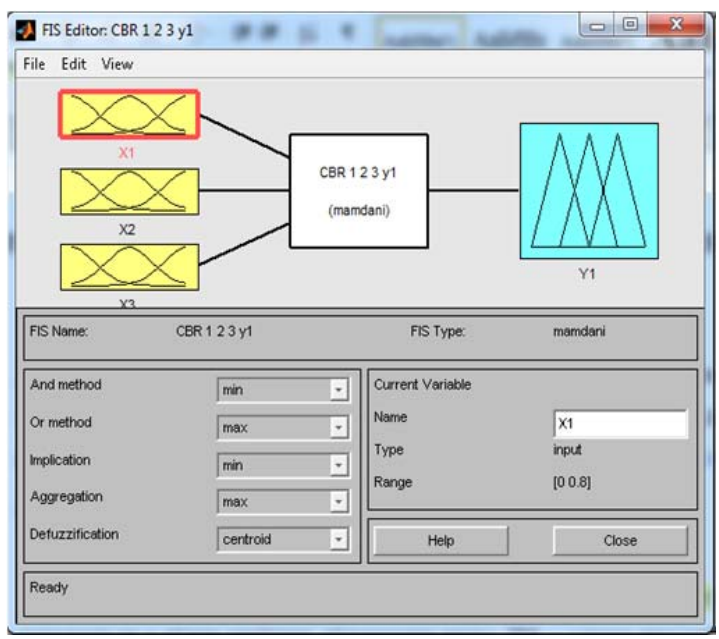

Figure 4. FisEditor

Source: Authors' calculations

The gradation of the development levels of the construction sector in the region iis as follows: EL «Extremely Low»; L - «Low»; M - «Medium»; H «High»; EH - «Extremely High». The construction of the fuzzy set is based on the Mamdani algorithm. Each condition is assigned a weighting factor $\left(\mathrm{R}_{\mathrm{i}}\right)$, that is assumedly equal 1 , according to the premise \{ Extremely Low (EL), Low (L), Medium (M), High (H), Extremely High (EH) $\}, i=1,5[10],[20]$ (Fig. 5; 6).

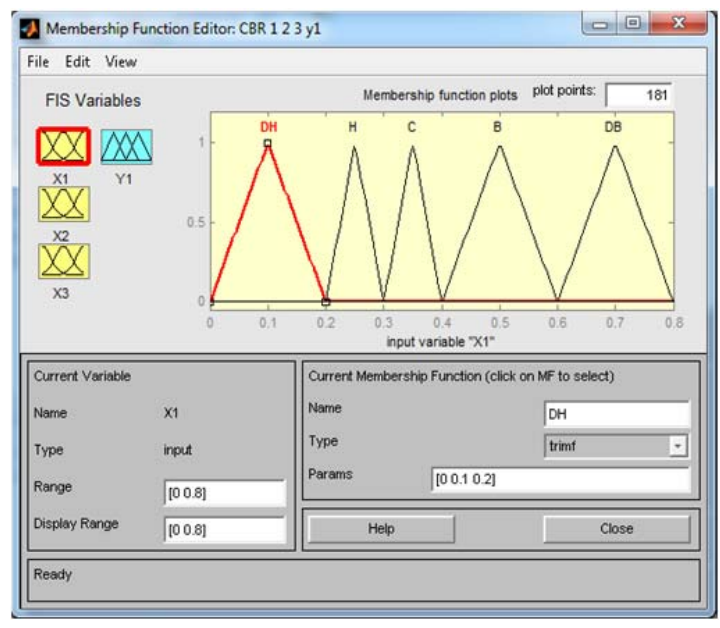

Figure 5. Graphical representation of the variable $x_{I}$ (MembershipFunctionEditor)

Source: Authors' calculations

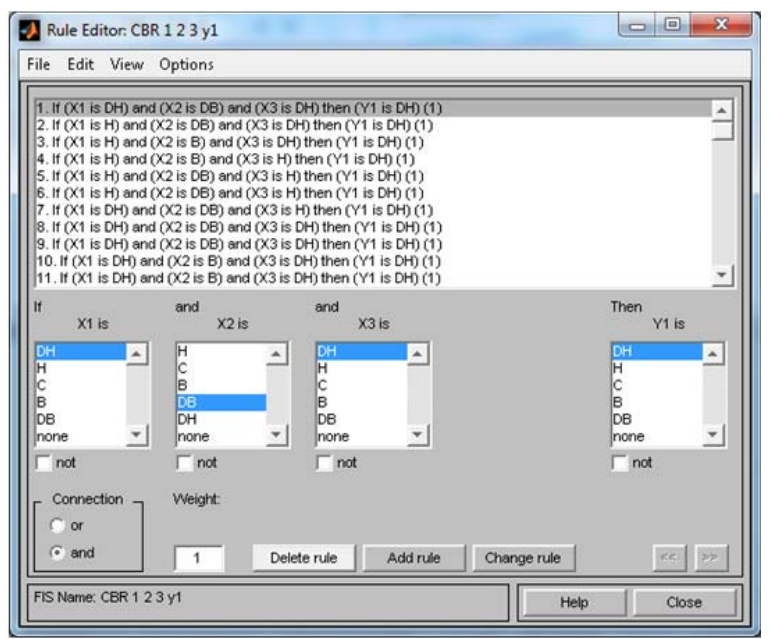

Figure 6. Fuzzy knowledge base in Mamdani (RuleEditor) Source: Authors' calculations

During fuzzyfication process the input variables due to the membership function obtain values of linguistic variables type, in the process of developing conditions, solutions and defuzzyfication, the fuzzy values acquire certain parameters (Fig. 7) [19],[21], [22].

Rule Base and Input data $X=\left(x_{i}\right)$ are on the "entrance", which contains the values of "input" variables $\left(x_{i}\right) \quad i=\overline{1,5}$ and "output" variable $(Y)$. Therefore the minimum value is determined [23]:

$$
a=\min \left\{x_{i}\right\},
$$

where $i=1, \mathrm{n}-$ number from an infinite quantity of sub-sets.

This step focuses on obtaining a set of "activated" membership functions [24]:

$$
\mu_{\mathrm{i}}^{\prime}(x)=\min \left\{d_{\mathrm{i}}, \mu_{\mathrm{i}}(x)\right\},
$$

where $\mu_{\mathrm{i}}^{\prime}(x)$ - "activated" membership function; $\mu_{\mathrm{i}}$ $(x)$ - term membership function; $d_{\mathrm{i}}-$ the degree of truth of i- sub-condition.

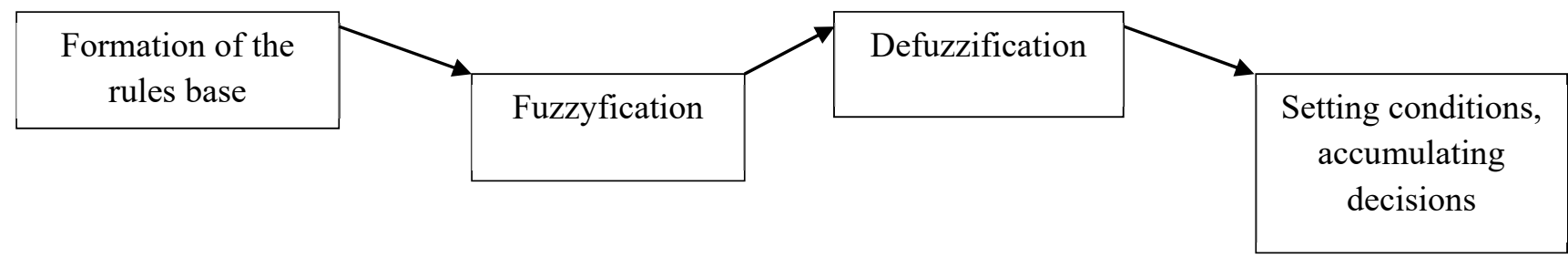

Figure 7. Fuzzy exit process scheme

Source: S. Shtovba, 2007; A.Borisov, at all, 1989; V.Zhukovin, 1983; L.Zadeh, 1976; Kofman, 1982; Leonenkov, 2005) 
The defuzzification aims to obtain quantitative values for each of the linguistic variables "source", by using the $i$-th variable "source" and the set $X_{i}$, which refers to it and by considering the total value of the variable source [25], [26].

$$
y_{i}=\frac{\int_{\operatorname{Min}}^{\operatorname{Max}} x \cdot \mu_{i}(x) d x}{\int_{\operatorname{Min}}^{\operatorname{Max}} \mu_{i}(x) d x}
$$

where

$\mu_{\mathrm{i}}(x)$ - the membership function to the corresponding fuzzy set $X_{i}$;

Min и Max - the limits of the entirety fuzzy variables;

$Y$ - result of defuzzification (Kofman, 1982) (Fig. 8).

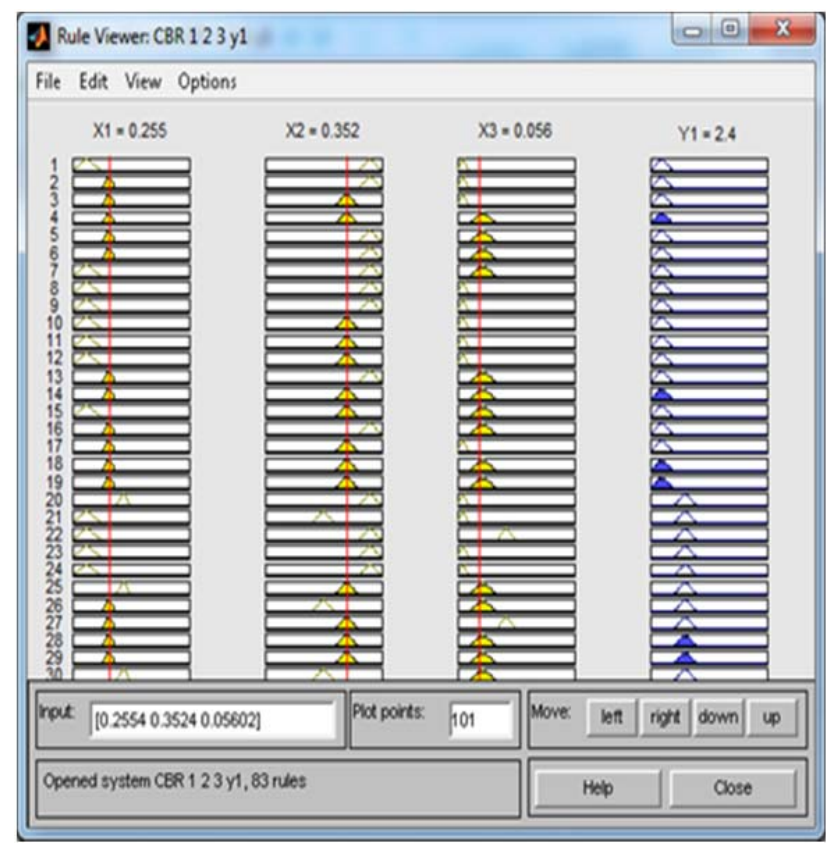

Figure 8. Applying Rule Viewer for Fuzzy Mamdani inference Visualization

Source: Authors' calculations

The revealed interconnections of the building subsystem with the complicated macro system of Ukraine are the basis for optimization of inner interconnections. Due to the low level of outgoing results (regions of Ukraine), the target parameter adopted a value above the average level. Thus, it is possible to obtain an indicator of the share of construction in the amount of GDP at 3\% under the preconditions, which is described in Fig. 10 and Table 3. 6 .

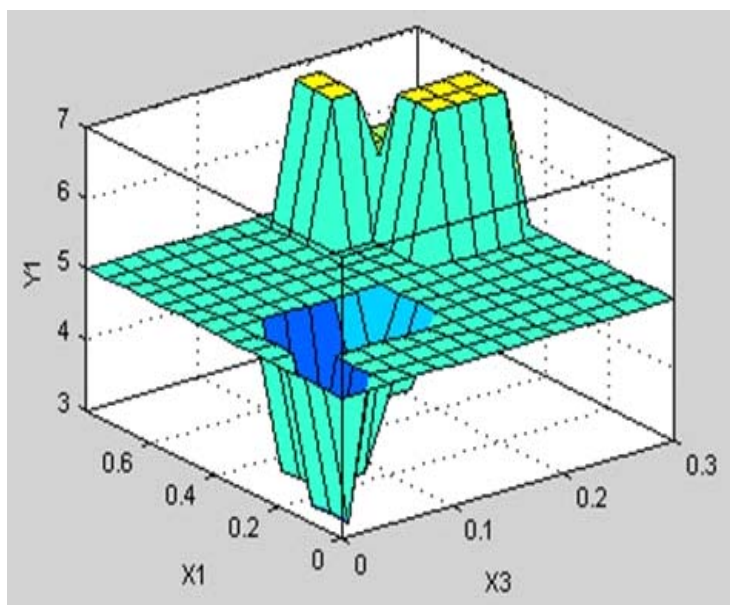

1)

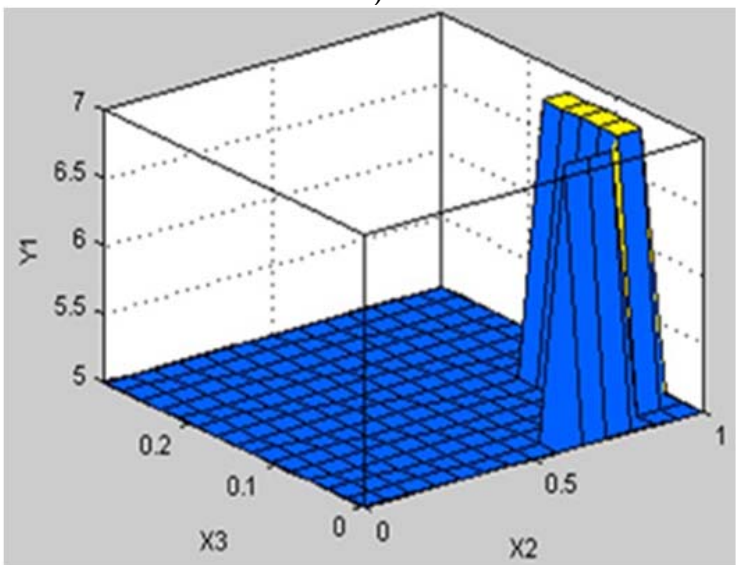

2)

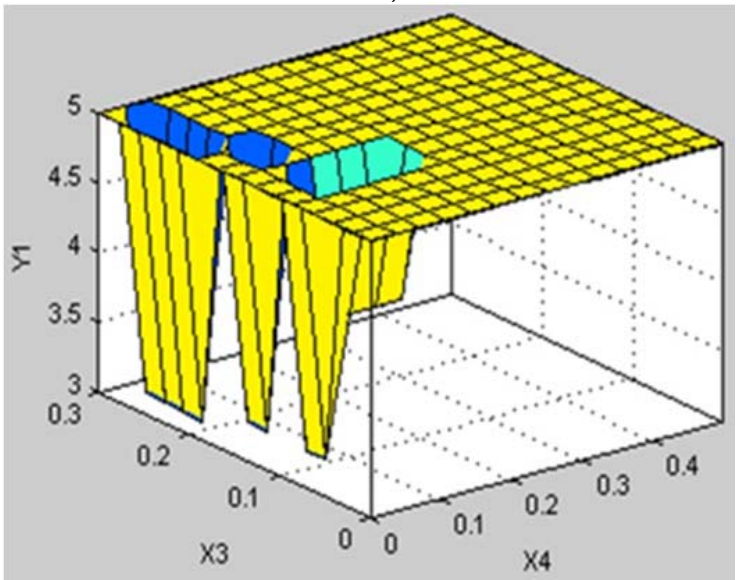

3)

1) interconnection between labor-resource $\left(x_{1}\right)$, raw material resource $\left(x_{3}\right)$ components and macrosystem $(Y)$;

2) interconnection between productive $\left(x_{2}\right)$, raw material resource $\left(x_{3}\right)$ components and macrosystem $(Y)$;

3 interconnection between raw material resource $\left(x_{3}\right)$, finance and investment $\left(x_{4}\right)$ components and macrosystem $(Y)$.

Figure 9. Fragment of three-dimensional surfaces of the predicted values of interconnections between elements of the subsystem in construction and macrosystem of the country

Source: Authors' calculations 


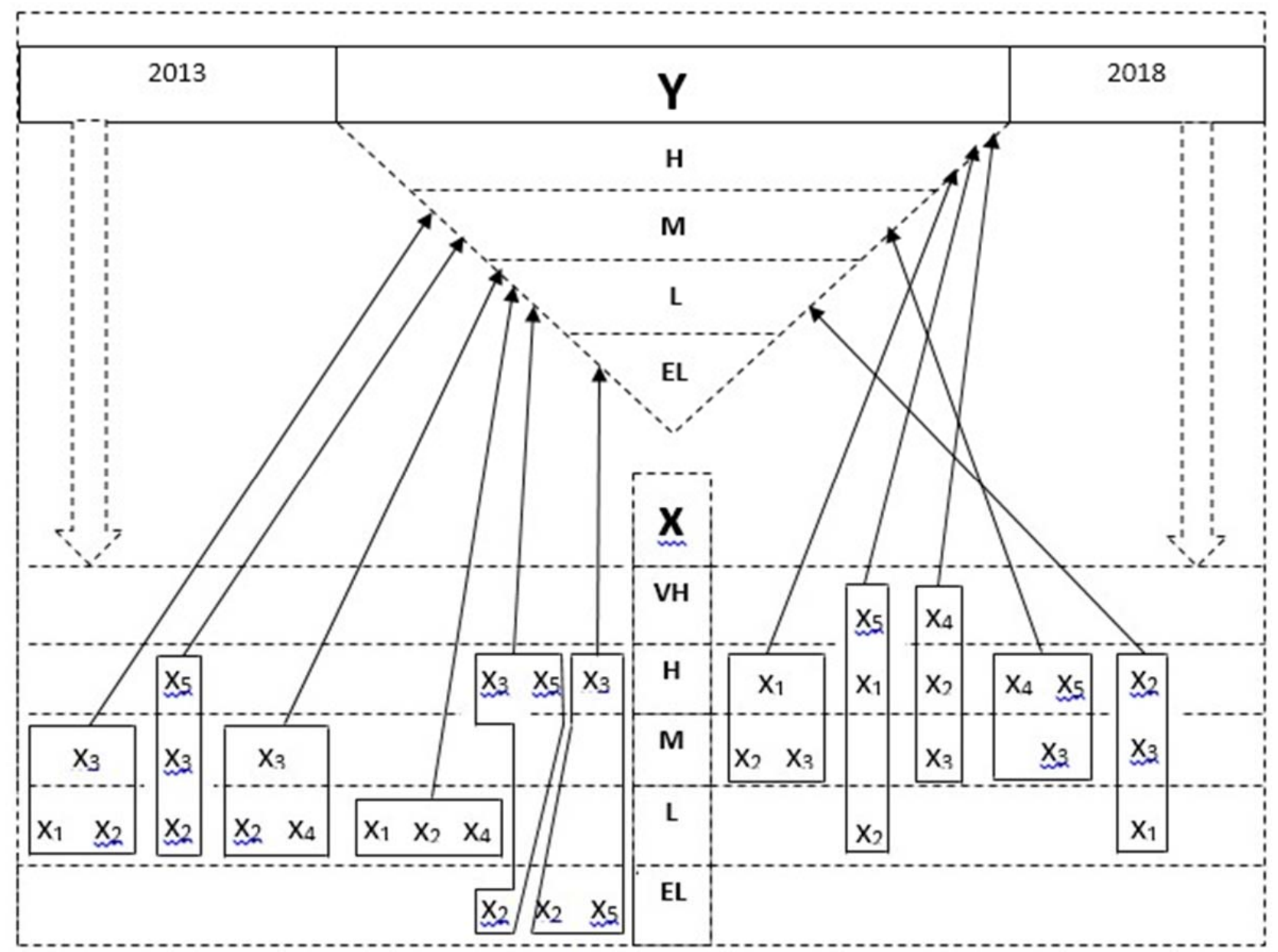

Figure 10. The revealed interconnections of the building subsystem with the complicated macro system of Ukraine, 2013, 2018 (VH - «Very High» level; H- «High»; M- «Medium»; L - «Low»; EL -«Extremely Low»)

Source: Developedby authors'

The obtained results reflect the dynamic changes of the interconnection between the main growth components of the construction subsystem and the country's macrosystem in 2013, 2018.

Table 3. A fragment of the model for the development of constituents of the subsystem of construction in the context of the impact on $G D P(Y)$

\begin{tabular}{|c|c|c|c|c|c|}
\hline $\begin{array}{c}\text { Integral } \\
\text { indicator of } \\
\text { labor-resource } \\
\text { element }\left(x_{1}\right)\end{array}$ & $\begin{array}{c}\text { Integral indicator } \\
\text { of productive } \\
\text { element } \\
\left(x_{2}\right)\end{array}$ & $\begin{array}{c}\text { Integral } \\
\text { indicator of } \\
\text { raw material } \\
\text { resource } \\
\text { element }\left(x_{3}\right)\end{array}$ & $\begin{array}{c}\text { Integral indicator } \\
\text { of finance and } \\
\text { investment } \\
\text { element }\left(x_{4}\right)\end{array}$ & $\begin{array}{c}\text { Integral } \\
\text { indicator of the } \\
\text { foreign } \\
\text { economic } \\
\text { element }\left(x_{5}\right)\end{array}$ & $\begin{array}{c}\text { Share of } \\
\text { construction in } \\
\text { GDP }(Y)\end{array}$ \\
\hline 0,236 & 0,717 & 0,136 & - & - & 3 \\
\hline- & 0,319 & 0,193 & 0,142 & - & 3 \\
\hline
\end{tabular}

Source: Authors' calculations

Thus, the scientific hypothesis concerning dynamic connections of construction subsystems, regional economies and national macrosystems is confirmed, which should be practically applied to determine the following rationally appropriate parameters:

1) the integral indicator of the labor force component of the construction subsystem should not be less than 0.236 units, typical of all regions of Ukraine;
2) the integral indicator of the productive element should reach 0.717 units, which concerns only the Kiev region; Interconnection $\left(x_{2}, x_{3}, x_{4} \rightarrow Y_{\mathrm{t}}\right)$ 0.319 units is suitable for the Ivano-Frankivsk, Kiev, Lviv, Odessa, Ternopil and Khmelnytsky regions;

3) the integral indicator of the raw material resource should be improved to the level of 0.136 units, is currently observed only in the Kyiv and Lviv region; the interconnection $\left(x_{2}, x_{3}, x_{4} \rightarrow Y_{\mathrm{t}}\right)$ at the 
level of 0.193 units is observed only in the Kiev region);

4) the integral indicator of the financial-investment element should reach the level of 0.142 units, is currently observed in Ivano-Frankivsk, Lviv, Nikolayev, Odessa, Ternopil, and Kharkiv regions.

The results of the analysis reflect the changes of features of the interconnection between the main components of the development in the construction sector and the country's macrosystem in the years 2013 and 2018. The use of the proposed methodological approach allows to confirm the scientific hypothesis regarding the regional features of the impact of construction components on the economy. In this case, construction companies can use the outlined relationships in the context of system-dynamic modeling of strategic priorities and mechanisms for their development, taking into account the strengths and weaknesses of construction components in particular regions. At the same time, the proposed methodological approach to modelling could be used in the process of studying the relationships of any subsystems with complex systems of different fields of research.

\section{Discussion}

Given the global trends of economic development in the construction sector, the synchronicity of the cyclical development of construction and the national economy have to be emphasized. The construction sector, like any economic system, is sensitive to cyclical fluctuations. However, in different periods of development, the construction industry affects the dynamic rhythms of socio-economic development of the state. Despite the length of the large economic cycle, the construction sector of the economy is also characterized by wavy dynamics. Thus, under conditions when the recession of the great cycle and the recession of construction coincide, the period of economic depression could be long, and it will have devastating consequences for the economic system. At the same time, the stage of raising in construction cycle during a period of declining fracture of the large cycle could reduce the duration and risks of the impact of the stage of depression on the economic development of the industry and the economy of the region / state as a whole. This functional dependence reflects the depth and duration of economic cycles, as well as allows us to objectively measure the dynamic efficiency of the construction industry.

Complementing the study with functional vertical and horizontal interconnections of components, should emphasize the consistency of the goals and objectives of the development of the construction sector and the socio-economic development of the state. At the same time, the regional development peculiarities of the subjects of the construction sector have different degrees of influence on the development of the industry. Therefore, the applying of principal components method and, accordingly, the orthogonal transformation of the indicators set into a set of variables without linear correlation seems appropriate in terms of calculating indicators of development in construction sector and economic growth of regions.

Due to the specific regional features of construction, the level of development of the potential of construction companies should be taken into account. Thus, one of the methods to assess the degree of use of the construction companies potential in the regional context can be DE analysis. When using this method, the input indicators should include indicators of the effectiveness of the development of the construction sector subjects, and the output - integrated indices of economic development of the regions. Classification of Ukrainian regions using the results of $\mathrm{DE}$ analysis could reveal the regions with high and low efficiency levels in the use of construction potential in order to ensure the economic development of the regions. The main tools which can be used to make a multidimensional statistical analysis of the dynamic relationships between the development of construction entities and the development of regions for the forecasting on the basis of the BCG-matrix are: correlation maps; method of taxonomic analysis, application of foresight methods and Holt's linear exponential smoothing.

The study revealed the differentiation of construction development in the regional frame. Thus, the reasons for the predominantly high level of financial and investment components in some regions were the financial stability of construction enterprises and the high industry investment potential in these regions. The presence of direct and indirect interrelations between the components of the construction sector and their influence on the change in the gross regional product led to the use of the fuzzy set method, and on the basis of the MatLab platform and the Fuzzy Logic Toolbox package, the process of fuzzy modeling of GRP state estimation under the influence of the construction sector components was automated.

\section{Conclusion}

The study shows the multiplier effect of economic development and efficient use of the construction companies potential. In order to ensure the industrial and technological development of the economy of Ukraine, the subjects of the construction sector need intensive and extensive transformations. Among the tasks of the state policy of construction development 
and reproduction of the potential in construction enterprises are financial and investment support for sustainable development, proactive policy of financing and lending to small businesses in the construction of socially significant projects in the regions, increasing housing construction, supporting global infrastructure projects, etc.

Modelling the construction sector development and its impact on the economic system of Ukraine on the basis of fuzzy logic methods allowed optimizing the value of components in relation to gross regional product. According to the calculations, the surfaces of their predicted values were formed, which allowed to determine the favorable levels of development of its components and, accordingly, the conditions for the operation of the construction enterprises, taking into account their regional peculiarities. Based on the results of aggregation of the main components of the Ukrainian construction sector in the regional context, their integrated development indices were determined. In addition, on the basis of the Mamdani algorithm, a fuzzy set was constructed and the levels of development in the construction sector by regions were established. This methodological approach served as a basis for modelling the optimal development of the construction sector in the macrosystem and calculating the prognosticated values of the relationship between the development of the construction sector and economic growth.

The results of the analysis show the dynamic changes in the interconnection between the main components of the growth of the construction subsystem and the country's macrosystem in the years 2013, 2018 and confirm the impact of construction components having regional features of construction on the state economy. The advantage of such a study is the high probability of choosing the optimal strategy for the development of construction companies, taking into account the potential of construction in particular regions.

Thus, the study of the growth of the regional economy should be conducted using a systematic modelling of the dynamic relationships of sectoral development and multidimensional statistical analysis of the development of enterprises in the construction sector by regions. Outlined scientific and methodological approaches to the study of interconnections of elements of micro- and mesolevel subsystems will contribute to form an effective system of economic relations between entities in the region, within which construction companies should be able to integrate into global infrastructure projects to increase industrial and technological potential at different levels of social hierarchy. Moreover, system-dynamic models of research on the development of the construction industry will serve us to develop effective strategic priorities for economic growth of the regions of Ukraine.

\section{References}

[1]. Kalinichenko, L. L., \& Sidorova, Y. R. (2017). Analysis of trends in the construction industry and construction products in Ukraine. Molodyj vchenyj, 4(44.4), 64-67.

[2]. Fisunenko, N. O. (2018). Pidkhody do doslidzhennia stanu budivelnoi haluzi [Approaches to the study of the state of the construction industry.]. Zabezpechennia staloho rozvytku ekonomiky: problemy, mozhlyvosti, perspektyvyEnsuring Sustainable Development of the Economy: Problems, Opportunities, Perspectives, 40-43.

[3]. Latysheva, O. V., \& Saiko, A. D. (2019). Construction industry of Ukraine: current state and its role in ensuring sustainable development of the national economy. Ekonomichnyi visnyk Donbasu, 2(56), 66-73.

[4]. Tatar, M. S. (2016). Doslidzhennia problem rozvytku resursnoho potentsialu budivelnykh pidpryiemstv Ukrainy v umovakh aktyvizatsii faktoriv zovnishnoho seredovyshcha [Research of problems of development of resource potential of construction enterprises of Ukraine in conditions of activation of environmental factors.]. Naukovyi visnyk Uzhhorodskoho natsionalnoho universytetu. Seriia: Mizhnarodni ekonomichni vidnosyny ta svitove hospodarstvoScientific herald of Uzhgorod National University. Series: International Economic Relations and World Economy, (6 part 3), 81-86.

[5]. Bohdan, N. M. (2012). Teoretychni aspekty zabezpechennya ekonomichnoyi bezpeky pidpryyemstv budivel'noho kompleksu v protsesi vzayemodiyi iz zovnishnim seredovyshchem. Efektyvna ekonomika, (10), 18-26.

[6]. T. Lichman. (2013). Klasyfikatsiya ta analiz zahroz bezpetsi komertsiynoyi tayemnytsi pidpryyemstva. Scientific journal of Odessa I. I. Mechnikov National University, № 18. Issue 1/1, 230-233.

[7]. K. Karpova. (2015). Analiz zahroz ekonomichniy bezpetsi budivel'nykh pidpryyemstv. Budivel'ne vyrobnytstvo. 58, 18-20.

[8]. T. Momot, I.Filatova, O. Tofaniuk. (2011). Ekonomichna bezpeka korporatyvnykh pidpryyemstv budivel'noyi haluzi. Ekonomika ta upravlinnya pidpryyemstvamy mashynobudivnoyi haluzi: problemy teoriyi ta praktyky. 2(14), 14-26.

[9]. Ilyash, O., Yildirim, O., Smoliar, L., Doroshkevych, D., Vasylciv, T., \& Lupak, R. (2020). Evaluation of enterprise investment attractiveness under circumstances of economic development. Bulletin of Geography. Socio-economic Series, 47(47), 95-113.

[10]. Anatoliy Mokiy, Mariia Pikh, Yuriy Pynda. (2019). Methodological Approach for Detecting Dynamic Characteristics of Interconnections of Subsystems and Complex Systems. 2019 IEEE 14th International Conference on Computer Sciences and Information Technologies (CSIT), September 17-20, 122-128. IEEE.

[11]. Pynda Yu.V. (2018). Stratehiya rozvytku budivel'noho sektoru. Ukrayiny: monograph. Lviv: Publishing house "Raster-7", 327. 
[12]. Sukhorukov, A.I., \& Kharazishvili, Yu.M. (2013). Shchodo metodolohii kompleksnoho otsiniuvannia skladnykiv ekonomichnoi bezpeky derzhavy [Regarding the methodology of complex estimation of components of economic state security]. Stratehichni priorytety, 3 (28), 5-15.

[13]. M. Klimenko,V.Feshchenko, N.Voznyuk. (2010). Osnovy ta metodolohiya naukovykh doslidzhen': navch. posib. K.: Ahrarna osvita, 2010, 351.

[14]. O. Rothstein. (1999). Intelektual'ni tekhnolohiyi identyfikatsiyi: nechitki mnozhyny, henetychni alhorytmy, neyronni merezhi. Vinnytsia: UniversumVinnytsia, 320.

[15]. Activity of business entities: statistical publication 2018. (2019). Kyiv: Ukrainian State Statistics Service. Retrieved from:

http://www.ukrstat.gov.ua. [accessed: 2 June 2020].

[16]. Kharazishvili, Y. M., \& Dron, E. V. (2014). Прогнозування індикаторів, порогових значень та рівня економічної безпеки України у середньостроковій перспективі [Prohnozuvannia indykatoriv, porohovykh znachen ta rivnia ekonomichnoi bezpeky Ukrainy u seredniostrokovii perspektyvi] (117 p.). Kyiv: NIS. Kyiv: NISS.

[17]. D. Antonyuk (2016) Modernizatsiya instytutsional'noyi infrastruktury pidpryyemnytstva rehionu $\mathrm{v}$ protsesi yevropeys'koyi intehratsiyi Ukrayiny: dissertation of Dr. Econ. sciences. Lviv, 464.
[18]. Hil, Charlz V. P. (2001). Mizhnarodnyy biznes: konkurentsiya na hlobal'nomu rynku: Per. z anhl. Oliynyk A., Tkachuk R. / Charlz V.L. Hil. - K.: Vyd-vo «Osnovy», - 856s.

[19]. I. Babets (2013). Stratehiya ekonomichnoyi bezpeky interrehional'noho spivrobitnytstva Ukrayiny V umovakh yevrointehratsiyi: dissertation of Dr. Econ. sciences. Kyiv, 2013, 422.

[20]. Shtovba, S. D. (2007). Proektirovanie nechetkikh sistem sredstvami MATLAB. Moscow: Goryachaya liniya-telekom, 288.

[21]. Borisov, A. N., Alekseev, A. V., \& Merkur'ev, G. V. (1989). Obrabotka nechetkoy informatsii v sistemakh prinyatiya resheniy. M.: Radio i svyaz.

[22]. Zhukovin, V. E. (1983). Multicriteria Decision Making Models with Uncertainty. Metsniereba, Tbilisi.

[23]. Zadeh, L. A. (1976). The concept of a linguistic variable and its application to the adoption of approximate solutions. Moscow: Mir, 165.

[24]. Kofman, A. (1982). Vvedenie v teoriyu nechetkikh mnozhestv. M.: Radio i svjaz.

[25]. Leonenkov, A. V. (2005). Nechetkoe modelirovanie $\mathrm{v}$ srede MATLAB i fuzzyTECH. $S P b .: \quad B H V$ Peterburg, 736.

[26]. Ilyash, O., Dzhadan, I., \& Ostasz, G. (2018). The influence of the industry's innovation activities indices on the industrial products' revenue of Ukraine. Economics and Sociology, 11 (4), 317-331. 